\title{
Assessment of early decline in the percentage of $\beta$-hCG values between days 0 and 4 after methotrexate therapy in ectopic pregnancy for the prediction of treatment success
}

\section{Ektopik gebelikte uygulanan metotreksat tedavisinden sonra 0 ile 4. günler arasında $\beta$-hCG değerlerindeki yüzde düşüşlerinin tedavi başarısını belirlemedeki yeri}

\author{
Ebru Çelik, Ilgın Türkçüoğlu, Abdullah Karaer, Pinar Kınıcı, Sevil Eraslan \\ Department of Obstetrics and Gynecology, Inönü University Faculty of Medicine, Malatya, Turkey
}

\section{Abstract}

Objective: To evaluate percentage changes in serum beta-human chorionic gonadotropin ( $\beta$-hCG) values between days $0-1,0-4$ and 0-7 as an indicator of methotrexate therapy success in extra-uterine pregnancies.

Material and Methods: Women with ectopic pregnancy treated with single-dose methotrexate therapy between January 2011 and August 2012 were assessed. Recorded data were reviewed electronically from patient files. All women $(n=93)$ with an ectopic pregnancy treated medically with intramuscular methotrexate $\left(50 \mathrm{mg} / \mathrm{m}^{2}\right)$ were included. The percentage changes in serum $\beta$-hCG levels from day 0 to 1 , day 0 to 4 and day 0 to 7 were calculated for each case.

Results: The median $\beta$-hCG values decreased between days 0 and 4 by $55.8 \%$, and $89.6 \%$ of these cases were treatment successes. The median initial serum $\beta$-hCG values were lower in women with successful treatment, but this was not statistically significant $(p=0.11)$.

Conclusion: A decline in serum $\beta$-hCG values between days 0 and 4 appears to be the best predictor. It would be beneficial to determine whether a woman with an ectopic pregnancy treated with singledose methotrexate administration will be treated successfully.

(J Turkish-German Gynecol Assoc 2013; 14: 125-9)

Key words: Ectopic pregnancy, human chorionic gonadotrophin, methotrexate.

Received: 8 April, 2013

Accepted: 26 May, 2013

\section{Özet}

Amaç: Ektopik gebeliklerin tedavisinde methotraksat tedavisinin başarısını belirlemede beta-human koryonik gonadotropin ( $\beta$-hCG) değerlerinin 0-1, 0-4 ve 0-7 günleri arasında yüzde değişimlerini değerlendirmek.

Gereç ve Yöntemler: Ocak 2011 ile Agustos 2012 tarihleri arasında ektopik gebelik nedeniyle tanı alan ve tek doz metotreksat tedavisi alan 93 olgu çalışmaya dahil edildi. Elektronik ortamda kaydelilen hastaların dosyalarında bulunan tüm bilgiler incelendi. $0-1,0-4$ ve $0-7$ günler arasındaki serum $\beta$-hCG seviyelerindeki değişim yüzdeleri her olgu için hesaplandı.

Bulgular: Metotreksat tedavisinin başarılı olan olguların \%55.8 ve $\% 89.6$ 'da ortanca $\beta$-hCG değerleri 0 ve 4 . günler arasında azalmış olarak bulundu. Tedavi öncesindeki ortanca $\beta$-hCG seviyesi tedavinin başarılı olduğu olgularda daha düşük saptanmasına rağmen iki grup arasında istatistiksel olarak bir fark saptanmadı $(\mathrm{p}=0.11)$.

Sonuç: Serum $\beta$-hCG değerlerindeki 0 ile 4 . günler arasındaki düşme olması metoteksat tedavisinin başarısını tahmininde en iyi gösterge olarak ortaya çıkmaktadır, ve tek doz metotreksat ile tedavi edilen ektopik gebeliklerin nihai tedavinin başarısını belirlemek yararlı olacaktIr. (J Turkish-German Gynecol Assoc 2013; 14: 125-9)

Anahtar kelimeler: Ektopik gebelik, human koryonik gonadotropin, metotreksat

Geliş Tarihi: 8 Nisan 2013

Kabul Tarihi: 26 Mayıs 2013

\section{Introduction}

Ectopic pregnancy (EP), with high maternal morbidity and mortality, is a real health problem. Its incidence is approximately $2 \%$ of all pregnancies (1). Early diagnosis of ectopic pregnancy and the option of conservative treatment have become possible by the use of sensitive human chorionic gonadotropin (hCG) and high-resolution transvaginal ultrasonography $(2,3)$. Methotrexate (MTX), a folic acid antagonist, is a common alternative treatment to surgery and has been confirmed to be effective, safe and cost-effective (4). Recruitment of eligible patients for MTX treatment is a key point to improve therapeutic response and reduce treatment failure. The single-dose MTX protocol is the most frequently used protocol, with a reported success rate of $65 \%$ to $94 \%$, as is associated with minimal toxic side effects, few complications and better compliance of patients (5-7).

Several variables, including gestational sac size, fetal cardiac activity, free fluid in the peritoneal cavity, serum progesterone and $\beta$-hCG levels, have been used as indicators for the predic- 
tion of MTX treatment success. The serum $\beta$-hCG level before MTX administration has been reported as a particular factor contributing significantly to treatment failure (8). Previously, it has been found that at least a $15 \%$ reduction in the $\beta$-hCG concentration on the seventh day compared to the fourth day after MTX administration is the best predictor of treatment success, with a positive predictive value of approximately $93.0 \%$ (9). A rise in the $\beta$-hCG titer on the fourth day after MTX compared to the pretreatment titer occurs in 50 to $70 \%$ of patients after MTX injection. However, this rise is not associated with the persistence of trophoblastic tissue (6). Furthermore, absolute measurements of $\beta$-hCG titers on day 4 after MTX administration have not been identified to be an anticipating factor of success of single-dose therapy (10).

Given the discrepancy between the results of previous publications, the aim of the current study was to determine whether percentage changes in serum beta-human chorionic gonadotropin ( $\beta$-hCG) values between days $0-1$ and $0-4$ are an indicator of methotrexate therapy success in ectopic pregnancy.

\section{Material and Methods}

The current study was a cross-sectional retrospective study, conducted on 93 consecutive ectopic pregnancies managed medically with methotrexate at İnönü University School of Medicine, Turgut Özal Medical Centre, between January 2011 and August 2012. Ethical approval was obtained from the institutional ethical committee of İnönü University. Recorded data were reviewed electronically from the files of patients. All women with an ectopic pregnancy treated medically with intramuscular methotrexate $\left(50 \mathrm{mg} / \mathrm{m}^{2}\right)$ met the following inclusion criteria: 1) no clinical suspicion of active intra-abdominal bleeding at the time of presentation 2) documented ultrasound diagnosis of extra-uterine pregnancy 3) the absence of trophoblastic tissue in the uterine cavity by pathological examination 4) subjects with $\beta$-hCG values on days 0,4 and 7 appropriately measured after medical treatment. Exclusion criteria included 1) incomplete records and patients who were lost to follow-up evaluation, 2) hemodynamic instability, 3) signs of acute abdomen and 4) abnormal hematologic, renal or hepatic laboratory values.

Only 93 of women who were managed with single-dose methotrexate therapy were eligible for the study; 38 had expectant management, 116 underwent surgery and 6 patients given medical therapy were excluded due to incomplete records. The demographic characteristics (age, gravidity, parity and abortus), physical examination (ectopic mass size calculated as the mean of the largest diameter and the diameter perpendicular to it) and laboratory values before and after treatment (serum $\beta$-hCG levels on days 0, 1, 4 and 7 after MTX injection) were collected by reviewing the medical charts of patients from the hospital. The success of medical treatment was defined as at least a $15 \%$ decrease in the serum $\beta$-hCG level on day 7 compared to day 4 after MTX treatment. Successfully treated patients were followed weekly by assessing serum $\beta$-hCG levels until this decreased to a value $<5 \mathrm{mIU} / \mathrm{mL}$. Treatment failure was defined as the need for either a second methotrexate injec- tion or surgical removal of the ectopic pregnancy mass due to less than a $15 \%$ decrease in the $\beta$-hCG level on day 7 compared to day 4 .

The serum $\beta$-hCG titer at the time of MTX administration was defined as the baseline value. Thus, day 1, 4 (hCG4) and 7 (hCG7) measurements were carried out after methotrexate administration. The percentage change in the serum $\beta$-hCG level from day 0 to 1 , day 0 to 4 and day 0 to 7 were calculated for each case as: (the latter $\beta$-hCG level minus the former $\beta$-hCG level) divided by the former $\beta$-hCG level and then multiplied by 100 .

\section{Statistical analysis}

Differences between mean and median values were compared by Student's t-tests for the continuous variables. Categorical variables, presented as numbers and percentages, were compared using the Chi-square test between the groups. Results are expressed as median and interquartile range (IQR) or percentage and number, as appropriate. The cutoff points for defining altered percentages of $\beta$-hCG levels that predict the success of MTX treatment were determined by performing receiver operator characteristic (ROC) curve analysis. A probability value $<0.05$ was considered statistically significant throughout the statistical analysis.

\section{Results}

The demographic features and clinical findings are presented in Table 1 . The median and IQR of age was similar in both groups $(p=0.48)$. There were also no significant differences between the groups in terms of obstetric history such as gravidity, parity and abortion ( $p=0.69, p=0.70$, and $p=0.67$, respectively). In the successful group, the mean size of the mass was smaller than in the failure group $(\mathrm{p}=0.05)$.

Methotrexate treatment in patients with ectopic pregnancy was successful in 71 cases $(76.3 \%)$, but the medical treatment failed in 22 cases $(23.7 \%)$. Of these 22 cases, 14 cases underwent surgery due to acute abdominal pain or rupture of the ectopic gestational sac, and a second dose of methotrexate was administered to eight cases. The median $\beta$-hCG values rose between days 0 and 1 in $54.3 \%$ of cases, between days 0 and 4 in $63.4 \%$, and between days 0 and 7 in $85.1 \%$ of cases. In cases with decreased $\beta$-hCG levels between days 0 and 4 , the success rate of treatment was $88.2 \%$. Figure 1 presents the course of mean serum $\beta$-hCG values for each group.

Although the median and IQR of the initial $\beta$-hCG values measured before MTX administration was lower in the successfully treated group in comparison with patients with treatment failure, the difference was not statistically significant $(p=0.11)$. A considerable difference in the median $\beta$-hCG value was noted on the first day $(p=0.03)$, the fourth day $(p=0.01)$ and the seventh day after MTX administration $(p=0.007)$. In the success group, 47 cases $(66.2 \%)$ had an initial $\beta$-hCG value below 2000 $\mathrm{mIU} / \mathrm{mL}$, while in the treatment failure group, 13 cases (59.1\%) had levels below $2000 \mathrm{mIU} / \mathrm{mL}(\mathrm{p}=0.54)$. The median and IQR of serum $\beta$-hCG concentrations and percentage changes are presented in Table 2 . 
Table 1. Comparison of demographic features and $\beta$-hCG variables in the two groups

\begin{tabular}{|c|c|c|c|}
\hline \multirow[b]{2}{*}{ Baseline characteristics } & \multicolumn{2}{|c|}{ Methotrexate treatment $(n=93)$} & \multirow[b]{2}{*}{ p value } \\
\hline & $\begin{array}{l}\text { Success group } \\
\quad(n=71)\end{array}$ & $\begin{array}{l}\text { Failure group } \\
\quad(n=22)\end{array}$ & \\
\hline Age, years & $29(25-33)$ & $30.5(27-32)$ & 0.48 \\
\hline Gravidity & $2(1-3)$ & $2(1-4)$ & 0.69 \\
\hline Parity & $1(0-2)$ & $1(0-2)$ & 0.70 \\
\hline Free fluid on transvaginal ultrasonographya, n (\%) & $26(36.6 \%)$ & $10(45.4 \%)$ & 0.42 \\
\hline Fetal heart activity present, n (\%) & $2(2.8 \%)$ & $2(9.1 \%)$ & 0.25 \\
\hline
\end{tabular}

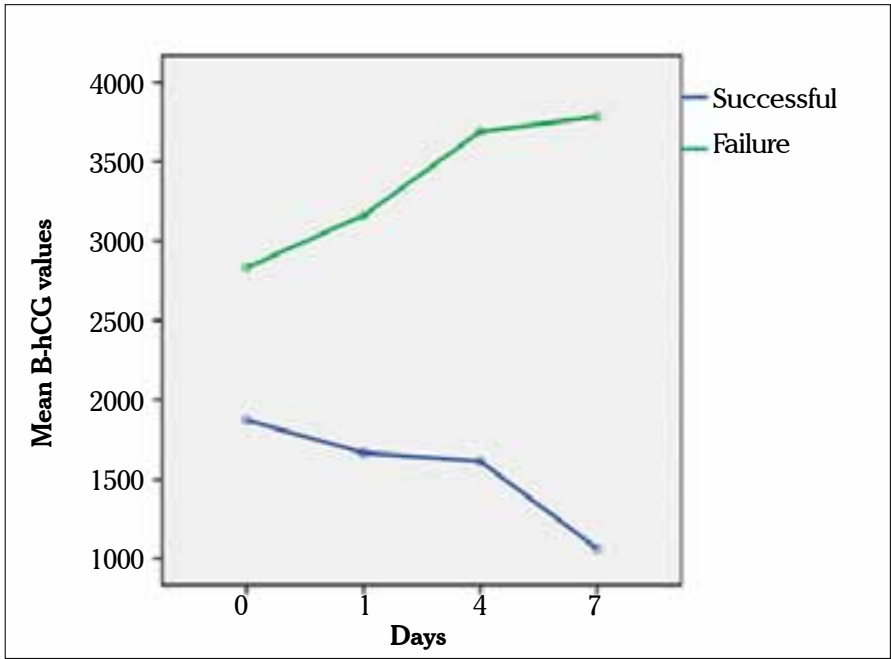

Figure 1. The mean values of serum $\beta$-hCG plotted against days after methotrexate injection in the two groups.

In the successful MTX group, the percentage decrease in serum $\beta$-hCG values between days 0 and 1 , days 0 and 4 and days 0 and 7 were $54.3 \%, 63.4 \%$ and $85.1 \%$ of cases, respectively. The entire data set was divided into three groups: 1) the percentage changes in serum $\beta$-hCG values between days 0 and 1,2) the percentage changes in serum $\beta$-hCG values between days 0 and 4 , and 3 ) the percentage changes in serum $\beta$-hCG values between days 0 and 7 . The results of the ROC curve analysis indicate that Group 1 had an area under the curve of $0.63(95 \%$ confidence interval (CI), 0.49-0.76; $\mathrm{p}=0.09$ ), with a sensitivity of $52.9 \%$, specificity of $65.0 \%$, positive predictive value (PPV) of $45.6 \%$ and a negative predictive value (NPV) of $55.2 \%$ in terms of identifying which patients were successfully treated with a single dose of MTX. The results of the ROC curve analysis indicate that Group $2(\geq 1.36 \%)$ had an area under the curve of 0.69 (95\% CI, $0.58-0.82 ; \mathrm{p}=0.007)$, with a sensitivity of $61.8 \%$, specificity of $70.0 \%$, PPV of $47.6 \%$ and NPV of $53.1 \%$ in terms of identifying which patients were successfully treated with a single dose of MTX. The results of the ROC curve analysis indicate that Group $3(\geq 0.18 \%)$ had an area under the curve of $0.79(95 \% \mathrm{CI}, 0.68-0.91 ; \mathrm{p}<0.001)$, with a sensitivity of $83.8 \%$, specificity of $60.0 \%$, PPV of $58.9 \%$, and NPV of $41.7 \%$ in terms of identifying which patients were successfully treated with a single dose of MTX. Furthermore, using the ROC curves, the calculated threshold percentage change between day 0 and 4 of $-9.088 \%$ had a sensitivity of $67.6 \%$, specificity of $70 \%$, NPV of $49.8 \%$ and PPV of $50.8 \%$ in terms of identifying which patients failed treatment. The analysis of logistic regression of the value of this cutoff showed an increased risk of treatment failure with an OR of 4.94 (95\% CI 2.67-9.13). The results of the ROC curves are presented in Figure 2.

\section{Discussion}

The overall success rate of methotrexate treatment in this study was $76.3 \%$, which is essentially in accordance with that reported by the two previous reports $(11,12)$. In the present study, a $63.4 \%$ probability of treatment success was found to be related to a rise in serum $\beta$-hCG values between days 0 and 4 , which is similar to that indicated by Nguyen et al. (11). However, others have noted lower success rates in that population (13).

Several studies have attempted to ascertain indicators of success after medical treatment of EP $(2,14,15)$. Different markers and features of EP have been studied to predict the outcome of treatment approaches $(6,16,17)$. Yet, the best predictive marker of medical treatment success for EP has clearly been identified. A recent meta-analysis suggested that the initial $\beta$-hCG level is the most important predictor of MTX treatment success in EP (18). Although it did not reach a statistically significant level, the median initial $\beta$-hCG concentration was correlated with the treatment success rate. Undoubtedly, women with a declining trend in the $\beta$-hCG level benefited from methotrexate treatment for EP. The results of this study are in accordance with previous reports (11, 19-21). Stika et al. (13) demonstrated that the pretreatment $\beta$-hCG concentration was higher in women with treatment failure than those who were successfully treated with a single dose of MTX. A recent study including 238 patients also found that the initial $\beta$-hCG value is the most important predictor of the outcome of treatment (22).

The findings of this study mainly confirm the results of Skubisz et al. (12), who found that an early decline in serum the $\beta$-hCG 
Table 2. Comparison of serum $\beta$-hCG values in the two groups

\begin{tabular}{|c|c|c|c|}
\hline \multirow[b]{2}{*}{ Baseline characteristics } & \multicolumn{2}{|c|}{ Methotrexate treatment $(n=93)$} & \multirow[b]{2}{*}{ p value } \\
\hline & $\begin{array}{l}\text { Success group } \\
\quad(n=71)\end{array}$ & $\begin{array}{l}\text { Failure group } \\
\quad(n=22)\end{array}$ & \\
\hline Initial $\beta$-hCG levels & $1341.5(647.0-2294.8)$ & $1595.0(570.7-3587.3)$ & 0.11 \\
\hline $\begin{array}{l}\beta \text {-hCG levels on the first day after MTX } \\
\text { administration, } \mathrm{mIU} / \mathrm{mL}\end{array}$ & $1413.5(637.8-2164.0)$ & $1702.5(782.3-3380.5)$ & $0.03^{*}$ \\
\hline $\begin{array}{l}\beta \text {-hCG levels on the fourth day after MTX } \\
\text { administration, } \mathrm{mIU} / \mathrm{mL}\end{array}$ & $870.5(483.5-2220.0)$ & $2268.5(526.3-6137.5)$ & $0.01 *$ \\
\hline $\begin{array}{l}\beta \text {-hCG levels on the seventh day after MTX } \\
\text { administration, } \mathrm{mIU} / \mathrm{mL}\end{array}$ & $537.0(202.5-1514.3)$ & $2299.5(431.3-7274.8)$ & $0.007^{*}$ \\
\hline $\begin{array}{l}\text { The percentage difference in } \beta \text {-hCG } \\
\text { levels between day } 0 \text { and } 1\end{array}$ & $1.09(-11.12-22.34)$ & $-4.07(-15.24-7.62)$ & $0.02 *$ \\
\hline $\begin{array}{l}\text { The percentage difference in } \beta \text {-hCG } \\
\text { levels between day } 0 \text { and } 4\end{array}$ & $12.77(-19.06-49.57)$ & $-31.16(-60.73-12.34)$ & $0.002 *$ \\
\hline $\begin{array}{l}\text { The percentage difference in } \beta \text {-hCG } \\
\text { levels between day } 0 \text { and } 7\end{array}$ & $42.31(19.44-79.64)$ & $-18.26(-68.16-19.44)$ & $0.001 *$ \\
\hline
\end{tabular}

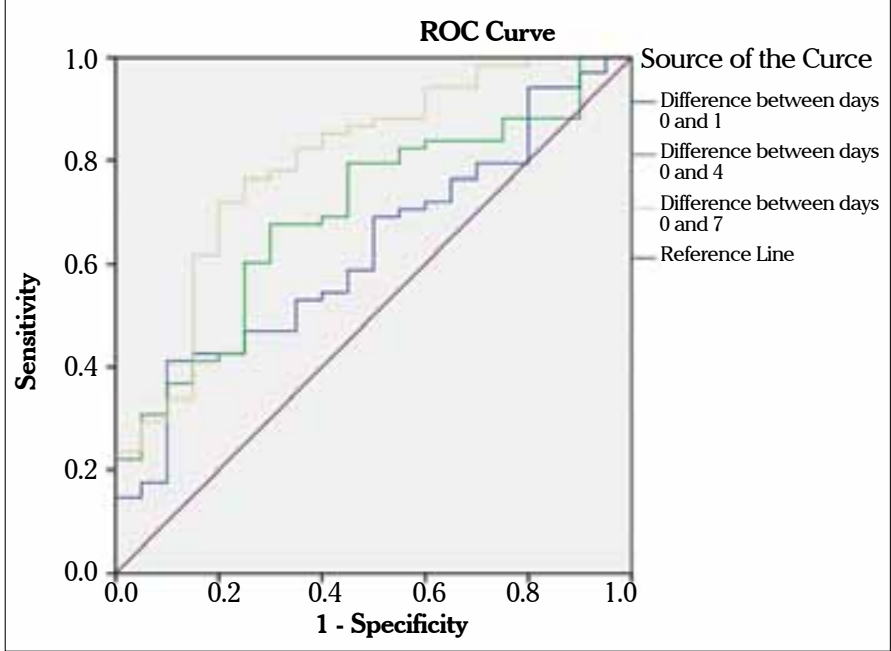

Figure 2. The ROC curves of percentage changes in serum $\beta$-hCG values between days $0-1,0-4$ and 0-7.

value between days 0 and 4 was associated with a high rate of treatment success (88\%). However, in the success group, $66.2 \%$ of patients had an initial $\beta$-hCG value below $2000 \mathrm{mIU} /$ $\mathrm{mL}$, and these cases would have undergone spontaneous resolution if they had been treated with expectant management. Considering our similar success rate (89.6\%), we support the notion that an early decline in the serum $\beta$-hCG value is correlated with likely treatment success. In view of this similar rate, it appears to be unnecessary to measure $\beta$-hCG levels on the first day after MTX administration.

A previous study conducted by Agostini et al. (19) evaluated the use of early $\beta$-hCG percentage changes between days 1 and 4 after methotrexate administration as an indicator of treatment success. That study noted that an hCG index value of 0.2 (20\% decline) was associated with a very high probability of eventual treatment success, with a positive predictive value of $97 \%$. However, the present study indicated a lower success rate $(75.1 \%)$ in women with a decline in $\beta$-hCG percentage between days 1 and 4 after MTX administration. The explanation for this discrepancy may be that the sample size of the present study small.

One advantage of this study is that the data are applicable. The overall success rate of single-dose methotrexate therapy in this study was $76.3 \%$, which is similar to that reported in the literature, $65-96 \%(5-7,11)$. Our study mostly confirms the results of previous studies $(19,21,22)$ that noted a rate of treatment success of $88-100 \%$ in women with a decline in $\beta$-hCG between days 0 and 4 , which is similar to our result (88.2\%). Taken together, an early decline in serum $\beta$-hCG appears to be associated with a very high likelihood of successful treatment outcome. However, considering the $88.2 \%$ success rate, not $100 \%$, it would be logical to monitor serial $\beta$-hCG values subsequent to MTX administration until the ectopic pregnancy is completely resolved.

In conclusion, $\beta$-hCG difference variables may contribute to the prediction of persistent disease. Early detection of resistant disease can be managed promptly. We have found that a decline in serum $\beta$-hCG between days 0 and 4 is associated with a high rate of treatment success. The change in the serum $\beta$-hCG value between days 0 and 4 appears to be a reliable early indicator of the likely eventual outcome of medical therapy and contributes to identifying which patients have been successfully treated with a single dose of MTX.

Ethics Committee Approval: This study received ethics approval from İnönü University Ethics Committee on 07.12.2010 (reference number: 2010/128).

\section{Informed Consent: $N / A$}

Peer-review: Externally peer-reviewed.

Author contributions: Concept - E. C.., I.T., A.K.; Design - E.C.., I.T., A.K.; Supervision - E.C.., I.T., A.K.; Resource - E.C., I.T., A.K.; Materials - E.Ç., I.T., A.K.; Data Collection\&/or Processing - E.C.., P.K., S.E.; Analysis\&/or Interpretation - E.Ç., I.T., A.K.; Literature 
Search - E.Ç., P.K., S.E.; Writing - E.Ç.; Critical Reviews - E.Ç., I.T., A.K

Conflict of Interest: The aurhors decleared no conflict of interest.

Financial Disclosure: The aurhors decleared no financial disclosure.

\section{References}

1. Kriebs JM, Fahey JO. Ectopic pregnancy. J Midwifery Womens Health 2006; 51: 431-9. [CrossRef]

2. Shalev E, Yarom I, Bustan M, Weiner E, Ben-Shlomo I. Transvaginal sonography as the ultimate diagnostic tool for the management of ectopic pregnancy: experience with 840 cases. Fertil Steril 1998; 69: 62-5. [CrossRef]

3. Lehner R, Kucera E, Jirecek S, Egarter C, Husslein P. Ectopic pregnancy. Arch Gynecol Obstet 2000; 263: 87-92. [CrossRef]

4. Hejenius PJ, Mol F, Mol BW, Bossuyt PM, Ankum WM, van der Veen F. Interventions for tubal pregnancy. Cochrane Database Syst Rev 1 2007; CD000324.

5. Bixby S, Tello R, Kulihowska E. Presence of a yolk sac on transvaginal sonography is the most reliable predictor of single-dose methotrexate treatment failure in ectopic pregnancy. J Ultrasound Med 2005; 24: 591-8.

6. Stovall TG, Ling FW, Gray LA. Single dose methotrexate for the treatment of ectopic pregnancy. Obstet Gynecol 1991; 77: 754-7.

7. Stovall TG, Ling FW. Single dose MTX: an expanded clinical trial. Am J Obstet Gynecol 1993; 168: 1759-62. [CrossRef]

8. Lipscomb GH, McCord ML, Stovall TG, Huff G, Portera SG, Ling FW. Predictors of success of methotrexate treatment in women with tubal ectopic pregnancies. N Engl J Med 1999; 341: 1974-8. [CrossRef]

9. Kirk E, Condous G, Van Calster B, Haider Z, Van Huffel S, Timmerman $\mathrm{D}$, et al. A validation of the most commonly used protocol to predict the success of single-dose methotrexate in the treatment of ectopic pregnancy. Hum Reprod 2007; 22: 858-63. [CrossRef]

10. Gabbur N, Sherer DM, Hellmann M, Abdelmalek E, Phillip P, Abulafia O. Do serum beta-human chorionic gonadotropin levels on day 4 following MTX treatment of patients with ectopic pregnancy predict successful single dose therapy? Am J Perinatol 2006; 23: 193-6. [CrossRef]
11. Nguyen Q, Kapitz M, Downes K, Silva C. Are early human chorionic gonadotropin levels after methotrexate therapy a predictor of response in ectopic pregnancy? Am J Obstet Gynecol 2010; 202: 630.e1-5.

12. Skubisz MM, Li J, Wallace EM, Tong S. Decline in $\beta$-hCG levels between days 0 and 4 after a single dose of methotrexate for ectopic pregnancy predicts treatment success: a retrospective cohort study. BJOG 2011; 118: 1665-8. [CrossRef]

13. Stika CS, Anderson L, Frederiksen MC. Single-dose methotrexate for the treatment of ectopic pregnancy: Northwestern Memorial Hospital three-year experience. Am J Obstet Gynecol 1996; 174: 1840-6. [CrossRef]

14. Coste J, Bouyer J, Job-Spira N. Epidemiology of ectopic pregnancy: incidence and risk factors. Fertil Contracept Sex 1996; 24: 135-9.

15. Mol BW, Hajenius PJ, Engelsbel S, Ankun WM, Van der Veen F, Hemrika DJ, et al. Serum human chorionic gonadotropin measurement in the diagnosis of ectopic pregnancy when transvaginal sonog- raphy is inconclusive. Fertil Steril 1998; 70: 972-81. [CrossRef]

16. Barnhart KT, Gosman G, Ashby R, Sammel M. The medical management of ectopic pregnancy: a meta-analysis comparing "single dose" and "multidose" regimens. Obstet Gynecol 2003; 101: 778-84. [CrossRef]

17. Dudley PS, Heard MJ, Sangi-Haghpeykar H, Carson SA, Buster JE. Characterizing ectopic pregnancies that rupture despite treatment with methotrexate. Fertil Steril 2004; 82: 1374-8. [CrossRef]

18. Dilbaz S, Caliskan E, Dilbaz B, Degirmenci O, Haberal A. Predictors of methotrexate treatment failure in ectopic pregnancy. J Reprod Med 2006; 51: 87-93.

19. Agostini A, Blanc K, Ronda I, Romain F, Capelle M, Blanc B. Prognostic value of human chorionic gonadotropin changes after methotrexate injection for ectopic pregnancy. Fertil Steril 2007; 88: 504-6. [CrossRef]

20. Kirk E, Bourne T. The nonsurgical management of ectopic pregnancy. Curr Opin Obstet Gynecol 2006; 18: 587-93. [CrossRef]

21. Lipscomb GH, Stovall TG, Ling FW. Nonsurgical treatment of ectopic pregnancy. N Engl J Med 2000; 343; 1325-9. [CrossRef]

22. Sagiv R, Debby A, Feit H, Cohen-Sacher B, Keidar R, Golan A. The optimal cutoff serum level of human chorionic gonadotropin for efficacy of methotrexate treatment in women with extrauterine pregnancy. Int J Gynaecol Obstet 2012; 116: 101-4. [CrossRef] 